RYSZARD PANASIUK

University of Łódź

Department of Philosophy

ryszard.panasiuk@gmail.com

\title{
TADEUSZ KOTARBIŃSKI - A PHILOSOPHER AND A TEACHER
}

The $70^{\text {th }}$ anniversary of our university is an excellent occasion to reminisce about Tadeusz Kotarbiński, who - and few can still remember that - was the first rector of this institution. He performed this function in the difficult post-war years of 1945-1949. He organised, together with a group of his associates, a higher education facility in a city that had never had this kind of scientific research and didactic institution. They acted in a period when the traumas of occupation and war were still alive, in a time difficult not only due to political and social issues, but also because people suffered from the lack of basic elements necessary for everyday existence.

Despite all this, the University functioned more and more efficiently and among the many newly created study courses you could find philosophy, resurrected, you could say, after the war hiatus. Professor Kotarbiński assembled around him a rather numerous group of scholars, survivors from the ravages of war, and started to present the ideas which were formulated and developed - to a great extent thanks to him - at Polish universities, especially the University of Warsaw, where he taught in the years 1919-1939. He proved himself to be an outstanding lecturer. He gathered a big circle of students, among whom you can find names known not only in Poland.

Professor Kotarbiński not only belonged to a community of scholars but he also cofounded it. It was a community which took place in the books on the history of philosophy as the Lvov-Warsaw School. In that school - started by Kazimierz Twardowski in Lvov and famous for names like Stanisław Leśniewski, Jan Łukasiewicz, Alfred Tarski or Kazimierz Ajdukiewicz - Tadeusz Kotarbiński played a distinctive role. While those mentioned concentrated in their research mostly on formal logic, he put special emphasis on teaching logic together with the theory of language (semantics) and methodology of science - due to the character and scope of his interest as a philosopher. 
What did Kotarbiński have in mind when he thought philosophy'? "Philosophy is to be understood", we can read in one of his most important works, "as investigation of things about which science has not - so far or fundamentally - expressed its opinion, and things about which a sapient man wants to have some reasonable ideas that could be tied together into a uniform opinion about the world". It is then, generally speaking, a system of convictions characterised by a global approach to reality, complemented by the still discussed issue of recommendations regarding moral acts.

What we are dealing with here is a general declaration showing the basis of a system of ideas and convictions which are of fundamental importance to a person willing to live their lives in accordance with reason and dignity. In their contents, those ideas and convictions clearly go beyond what was considered to be the procedures and results of actions that were supposed to show the way to science, understood in the way that became so popular when the author of the mentioned piece developed his views as a philosopher.

As a result, the question of the mutual relationship between philosophy and science deserves a special highlight because of the idea that was more and more widespread in the second half of the $19^{\text {th }}$ century and the first half of the $20^{\text {th }}$, an idea which claimed that with the advancement of science, especially the natural sciences, matters which were traditionally considered to be philosophical were being reduced or, in a more extreme case, eliminated completely. Such ideas were presented by supporters of the school of thought commonly called positivism, popular in Western Europe. The strongest formulations of that opinion came from the representatives of the Vienna Circle.

Tadeusz Kotarbiński was of a different opinion. The longevity of ideas historically proposed by philosophers suggests that a person cannot give up looking for answers to which science provides no answers. They are also aware that the historical record that a modern person has access to is characterised by a multitude of viewpoints and ideas bearing witness to how limited their knowledge is about the world and about themselves. That record includes some beliefs about reality which today raise doubts, beliefs which were considered true by thinkers of the past but which today are plainly false yet are still presented as true to the public in the language of philosophical discourse. A good example of such attempts is the spread of religious ideas in the form of philosophical discourse.

A task presented to a representative for philosophy, which did go beyond the scientific horizon, but tried to be completely consistent with it - and such was the programme of the school that Kotarbiński was a member of - was all about conducting a critical analysis of those philosophical formulas. That critical

\footnotetext{
${ }^{1}$ KOTARBIŃSKI [1961].
} 
analysis was to be a procedure which could realise the call for an analytical deconstruction of the language of such philosophical discourse and which could result in uncovering the meaning hidden under "heaps of rubble" which had piled up throughout centuries of philosophical investigations. ${ }^{2}$

In contrast to natural scientists, philosophers do not have at their disposal the instruments that allow them to penetrate the subject of their investigation through, e.g. experimental procedures. They can only observe reality and express the results of those observations in language. Language constitutes the only instrument through which a philosopher can mediate the results of that analysis of reality. That is why it is so important to see how it functions in philosophical discourse.

Thus far, however, language as an isolated area of research had not been of special interest to many - which one can easily see when having a closer look at the history of philosophy. In modern philosophical thought that situation has changed drastically. There were two reasons for that shift of focus towards language among scholars in modern times, it seems: first of all, it was due to the dissatisfaction with its previous forms of expression in philosophy as shown by its lack of precision in formulating claims, its ambiguities and even formulating ideas which, on closer inspection, were nonsensical. The second reason was connected with the increasing scepticism created by the advancement of applied methods in natural sciences regarding the possibility of ever reaching in a cognitive act any extrasensory reality, reaching an ontological system existing independently in a form beyond an act of sensory perception.

Tadeusz Kotarbiński did not share the views of those radical sceptics. He was of the opinion that a cognitive act should not be limited to perception of phenomena, and that the claim suggesting that nothing exists beyond them is unwarranted. He was convinced that a cognitive act refers to real entities, actually existing beyond human awareness. Moreover, he believed that those entities are indeed individual corporeal objects which included human existences.

For that reason, he declared an ontological position he called reism, concretism or somatism. ${ }^{3}$ By rejecting the existence of individual immaterial entities - as often happened in the case of earlier thinkers - he presented himself as a materialist. That radically concretistic and materialistic ontology was - as he himself admits - a result of his relfection on language as a tool for describing experiences. It turned out that, when closely scrutinised, not only common ways of talking but the whole of language is a deceptive tool for describing reality. For example, general expressions used in sentences suggest that their meaning refers to entities characterised by that generality.

\footnotetext{
${ }^{2}$ See KOTARBIŃSKI [1958], paper: "Kultura filozoficzna".

${ }^{3}$ See KOTARBIŃSKI [1958], paper: "O postawie reistycznej, czyli konkrety stycznej”.
} 
Such a position was, as we know, presented by Plato. Hence, the idea that apart from individual objects there exist general entities (unviersals) is called Platonism. What's more, a common way of talking may suggest that states of things, changes and relations exist independently of individual objects. For example, the phrase "extensibility characterises all bodies" suggests that this extensibility can exist as an entity independent of those bodies.

It may be worth mentioning that this radical "concretistic" approach of Kotarbiński came under attack especially from mathematicians. With time, he decided not to defend it to the letter claiming the he would keep it just as a programme. ${ }^{4}$ When it comes to the semantic sphere of his idea, regarding the way we should speak about the results of cognitive acts with any sense, he remained true to his beliefs.

Another area of philosophical investigation of Professor Kotarbiński was ethics. His considerations about such an important - and still present in his biography - reflection about good and evil started very early in his life and he considered them to be the most important part of the system of beliefs he was developing. ${ }^{5}$ We say that because we are dealing here with a sketch of a system and those who treat reism, the ethics of a reliable guardian, and praxeology as not connected in any way are simply wrong.

The core of Kotarbiński's system is the human being. Human beings are thinking and active, which means that they learn about the world and, at the same time, through their rational actions shape the area they inhabit as social beings. These are the forms of socialisation historically shaped by them and forms of spiritual culture associated with them. To act in such a way, you need not only the knowledge about the object of such actions but also a system of values which will not only guide them but also create a special kind of relationship between agents.

That action, taken consciously on the basis of the known state of things and intended goals, has two basic forms. The first form is a system of values which a human being acquires in the process of historic self-education, while the other is connected with purely practical actions in a technical sense. It's about actions whose result is to form the surroundings in such a way that they take the best shape for meeting people's basic needs. This area of human activity is a separate subject of interest for the Philosopher and takes the form of a theoretical concept about human actions which he called praxeology.

When it comes to ethics, Tadeusz Kotarbiński opposes both the traditionalists, who refer to transcendental ideas for moral guidance, and the proponents of

\footnotetext{
${ }^{4}$ See KOTARBIŃSKI [1961], and his "Fazy rozwojowe konkretyzmu".

${ }^{5}$ See MAŁACHOWSKI [1972], p. 4.
} 
more modern ideas, who support radical naturalism rooted in Darwinism. Since the very beginning of his creative career, Kotarbiński critically deconstructed the ethical ideas of Spencer and Mill. He also thought that eudemonism suggested by some ancient philosophers was unacceptable. The professor preferred the ethics of the Gospel, with its idea of goodness and sacrifice. ${ }^{6}$ The main goal there is to help a fellow creature in need and not to seek your own individual happiness. A person willing to live with dignity should be characterised by prudence, intellectual maturity, which makes it possible to learn the true state of things in relationships between people. They should be characterised by courage in situations when it is necessary to defend anyone in danger of suffering or being harmed; they are obliged to keep their word and be able to act in critical situations against their interest. It is a kind of ethics, then, which demands that one's beliefs are followed by their corresponding actions.

The author of that moral programme believed that humans, as rational beings, are able to distinguish between good and evil without needing to refer to any commands or suggestions allegedly coming from outside the domain of experience. In that sense, we are dealing here with a system of ethics independent of those commands or suggestions, one in which a human is their own lawmaker. The moral system thusly understood cannot be threatened by any loss of faith in the transcendental.

The rational approach to the question of morality brings to mind a sort of minimalism, best presented in the famous formula of reliable guardianship. ${ }^{7}$ The superior virtue here is not the happiness of an individual but helping any fellow being threatened by suffering or harm. Kotarbiński - a realist and a proponent of prudence and moderation - considered the maximalistic programmes of universal happiness of humankind as utopian phantasies.

Another early interest of Professor Kotarbiński was the question of practical actions of a person trying to achieve a desired result. He published a comprehensive treatise Szkice praktyczne (Practical drafts) as early as in 1913. He came back to this topic many times, but it wasn't until after World War II that he made the effort to present in detail the issues of the so-called praxeology. It is worth noting that Traktat o dobrej robocie (A Treatise on Good Work), the work devoted to the topic, published in 1955 under the aegis of Łódzkie Towarzystwo Naukowe, was created for the most part during the time its author was the rector of our University.

It is difficult to present here in much detail the ideas described in the treatise. Broadly speaking, the author wanted to develop a general theory of action because he believed that the practical activity of a thinking being is an important

\footnotetext{
${ }^{6}$ See KOTARBIŃSKI [1957] and the paper "O tak zwanej miłości bliźniego".

${ }^{7}$ See WOLEŃSKI [1990], p. 137.
} 
element of human existence. In this regard, praxeology must be recognised as an important element of the construct of the systemic philosophy of man that Kotarbiński created.

Thus, a separate scientific discipline was founded, one that laid the foundations for any analyses of human practical activities. The publication of the mentioned Treatise inspired the work of scholars who found the ideas presented there appealing. Scientific research facilities were created together with a scientific society, bringing together scholars interested in praxeology. It also gave a theoretical basis to the thriving research on the organisation of work, collaboration and the cooperation of multidisciplinary production groups.

That is the shortest possible summary of the philosophical ideas of Tadeusz Kotarbiński. His image, however, would be incomplete if we said nothing about his educational work.

Kotarbiński began teaching in 1912 in the Mikołaj Rej High School in Warsaw, where he taught Latin and Greek. From 1919 until the beginning of the World War II he taught logic and methodology of science to students of University of Warsaw. He continued his educational work throughout the time of occupation and after the war until he retired. His almost 25-year-long educational career bore fruit in the form of numerous groups of students, many of whom were later recognised as excellent philosophers. His educational excellence is proven by the fact that his students published out of gratitude no fewer than three commemorative books devoted to his work.

An important complement of Professor Kotarbiński's educational work was numerous publications on teaching philosophy, didactics and course books. Undoubtedly the most important among them was a comprehensive study on the theory of cognition, logic and methodology of science called Elements. This work was treated by its author as an instrument of didactics, just a course book, but the ideas and concepts presented there, as well as its public reception and the number of languages it has been translated into, suggest that it's more than that. Elements of the Theory of Cognition, Formal Logic and Methodology of Science is undoubtedly Kotarbiński's opus magnum, a treatise presenting the important contents of his philosophical ideas.

This work, published for the first time in 1927, is complemented by, among lesser treatises on didactics, Lectures from the history of Logic. That book, published in 1957, comprised lectures for philosophy students at the University of Warsaw that Kotarbiński gave in the years 1952-1957. Anyone who studied law at the University of Łódź in the post-war years, as well as later philosophy students, should remember $A$ course of logic for lawyers. It goes without saying that those didactic publications are characterised by accessibility, clarity and richness of information about the subject they refer to. 
At the end, let us try and answer the question of who Tadeusz Kotarbiński was as a teacher and a person whom not many of those still alive had the chance to meet. He treated his educational work as his civic duty, consisting in not only educational competence, reliability and clarity of thought, but also in developing in his students the characteristics and virtues he encapsulated in his idea of a man - honest, open to others, righteous and helpful in difficult situations. In his life he realised the ethos of the reliable guardian. I say that with deep conviction because I myself experienced not only his kindness, but also his help in situations that were difficult for me.

When it comes to social issues, he was a moderate realist. He distanced himself from the utopian visions and phantasies of the supporters of radical social revolution. He believed that through honest and just work, cooperation between people able to put a common good over their individual interests, one could build a social order in which the previous aches and pains of everyday life could be significantly reduced.

In the pre-war times he was critical of the social and political relations. He especially actively opposed the process of limiting freedom in the system of education, the clericalisation of the public sphere and the nationalist group running rampant in higher education facilities. After the war he actively joined the process of rebuilding the country by defending the freedom of expression and the freedom of discussion about social and political issues, which he voiced in articles printed in the press.

Kotarbiński was worried about the ongoing process of imposing the official doctrine on society, which was, as a result becoming trivialised and intellectually degraded. He was treated rather agreeably by the political powers, especially in the period of relative liberalism of the first years after the war. It might be the reason why he was given the opportunity to take the position of the rector of University of Łódź.

The situation worsened after 1948. From that time he was treated stiffly; critical remarks about his philosophical views were raised and his educational work was limited to just teaching logic.

The relative liberalisation of the social and political life that took place after the events of 1956 gave hope for a relaxation of civic liberties. It could be the reason why Kotarbiński was allowed to take the position of the president of the Polish Academy of Sciences which he held in the years 1957-1963.

The illusions did not last long, however. The ongoing curtailment of intellectual liberties encouraged active defiance against the policy of the party. And so Tadeusz Kotarbiński soon joined protestive actions undertaken by the intellectual opposition. He took part in discussions organised by a group of activists of Krzywe Koło, signed the famous "Letter of the 34", and participated in political 
processes as a protester against tendentious accusations. He strongly condemned the government for suppressing intellectual liberty in 1968 and especially the anti-Semitic background tone of its aggressive propaganda. He resigned from presiding over the committee of the editorial staff of the Classics of Philosophy in protest against the firing of Irena Krońska, an honoured editor of that publishing house. During one of the sessions of the Philosophy Committee he strongly condemned the expellment of scholars and students due to political and ethnic reasons.

Professor Kotarbiński as a thinker and a propagator of his views, especially those regarding social issues, world view and politics, had many friends and supporters. But he also had enemies. It was true for the time between the wars, the time of occupation as well as the post-war era. It was during the occupation that his life was threatened, not only by the occupiers. It is not a coincidence that his long educational work did not grant him a commemorative place on the columns of the new library of University of Warsaw.

Despite attempts to depreciate Tadeusz Kotarbiński's scientific and educational legacy - some of which are made even nowadays - we can be truly proud of our first Rector. Let us not allow such an exquisite scientific legacy and such a high moral authority to be ever forgotten.

\section{References}

KOTARBIŃSKI, T. [1957], Wybór pism (Selected Papers), vol. 1, PWN, Warszawa.

KOTARBIŃSKI, T. [1958], Wybór pism (Selected Papers), vol. 2, PWN, Warszawa.

KOTARBIŃSKI, T. [1961], Elementy teorii poznania, logiki formalnej i metodologii nauk (Elements of Theory of Knowledge, Formal Logic and Methodology of the Sciences), Ossolineum, pp. 452.

MAŁACHOWSKI, A. [1972], "Spotkanie z Tadeuszem Kotarbińskim" (Meeting with Tadeusz Kotarbiński), (an interview of A. Małachowski), Literatura, Nr 20.05.1972.

WOLEŃSKI, J. [1990], Kotarbiński, Wiedza Powszechna Press, Warszawa. 